\title{
Utilization of Wood Biomass for Organic Soil Based on the Soil Fertility Index (SOFIX)
}

\author{
Pitchayapa Pholkaw' ${ }^{1}$ Ayaka Muraji ${ }^{1}$, Kazuyoshi Maeda1, Taiki Kawagoe', Kenzo Kubota1, \\ Sirilak Sanpa ${ }^{2}$, Quoc Thinh Tran'1, Motoki Kubo' ${ }^{*}$
}

\footnotetext{
${ }^{1}$ Department of Biotechnology, Faculty of Life Sciences, Ritsumeikan University, Kusatsu, Shiga, Japan

${ }^{2}$ Division of Microbiology and Parasitology, School of Medical Science, University of Phayao, Phayao, Thailand

Email: *kubo@sk.ritsumei.ac.jp
}

How to cite this paper: Pholkaw, P., Muraji, A., Maeda, K., Kawagoe, T., Kubota, K., Sanpa, S., Tran, Q.T. and Kubo, M. (2019) Utilization of Wood Biomass for Organic Soil Based on the Soil Fertility Index (SOFIX). Journal of Agricultural Chemistry and Environment, 8, 224-236.

https://doi.org/10.4236/jacen.2019.84017

Received: October 23, 2019

Accepted: November 26, 2019

Published: November 29, 2019

Copyright $\odot 2019$ by author(s) and Scientific Research Publishing Inc. This work is licensed under the Creative Commons Attribution International License (CC BY 4.0).

http://creativecommons.org/licenses/by/4.0/

\begin{abstract}
Possibility of wood biomass for preparing organic soil was examined to construct reproducible and stable organic standard soil. Seven organic soils were constructed from base soils and additive materials based on the recommended values of the soil fertility index (SOFIX) (total carbon $\geq 25,000 \mathrm{mg} / \mathrm{kg}$, total nitrogen $\geq 1500 \mathrm{mg} / \mathrm{kg}$, total phosphorus $\geq 1100$, and total potassium of 2500 to $10,000 \mathrm{mg} / \mathrm{kg}$ ). Base soils were prepared from two types of wood biomass (big- and small-sized wood chips) at 50\%,60\%, and $70 \%(\mathrm{v} / \mathrm{v})$ and other organic materials such as peat moss, black soil, and mountain soil. Additive materials (soybean meal, oil cake, cow manure, and bone meal) were amended into all organic soils at the same amount. Incubation experiment showed that bacterial biomass in all organic soil was greater than $6 \times 10^{8}$ cells/g-soil after addition of $30 \%$ of water content for 1 week. In addition, polymerase chain reaction denaturing gradient gel electrophoresis (PCR-DGGE) analysis resulted in a stable bacterial diversity of the organic soil prepared from the small size wood chip at $70 \%$. Chemical properties of all organic soils were within the recommended values of SOFIX. The plant cultivation experiment showed that fresh Brassica rapa var. peruviridis weights in the organic soils with $50 \%, 60 \%$, and $70 \%$ of small-sized wood chip were $5 \%, 16 \%$, and $27 \%$ higher than that of the chemical fertilizer-amended soil. The organic soil with $70 \%$ of small wood chip was the best in the seven organic soils in this study.
\end{abstract}

\section{Keywords}

Wood Biomass, Organic Soil, Soil Fertility Index (SOFIX)

\section{Introduction}

Over the last century, agrochemicals such as chemical fertilizers and pesticides 
have been developed to enhance agricultural activities [1]. Crop and vegetable yields have been substantially enhanced but the chemicals have also increased the risk to human health and the environment. Chemical fertilizers and pesticides have the potential to cause a considerable environmental hazard, including the reduction in the numbers and activities of soil microorganisms [2] [3] [4] [5].

To protect soil microorganisms from the harmful effects of agrochemicals, it is necessary to either minimize the use of agrochemicals or increase the abundance and activities of soil microorganisms to accelerate the biodegradation process [6] [7]. Soil microorganisms represent one of the most important indicators for stable organic agriculture. Microorganisms play important roles in the decomposition of organic materials and the cycling of carbon, nitrogen, phosphorus, and several other nutrients in the soil [8] [9] [10] [11] [12].

Analysis of soils and organic materials can be used to determine the status of available nutrients. The soil fertility index (SOFIX) was developed considering the importance of physical, chemical, and biological soil characteristics [13]. More than 6000 agricultural soil samples (upland, paddy, and orchard fields) have been analyzed by the SOFIX. The suitable soil conditions for organic agriculture based on the SOFIX database are total carbon (TC) $\geq 25,000 \mathrm{mg} / \mathrm{kg}$, total nitrogen $(\mathrm{TN}) \geq 1500 \mathrm{mg} / \mathrm{kg}$, total phosphorus $(\mathrm{TP}) \geq 1100$, total potassium (TK) 2500 to $10,000 \mathrm{mg} / \mathrm{kg}$, and bacterial biomass $\geq 6 \times 10^{8}$ cells $/ \mathrm{g}$-soil.

Reproducible and stable organic soils with abundant microbial number and diversity are especially difficult to create, while it is willing to use for agriculture and scientific fields, because wood biomass is abundant not only in Japan but also over the world. Therefore, its utilization as soil amendment should be concerned. The previous experiments showed that wood chip from cedar leads to the increase of bacterial biomass [14]. This study aimed to construct a reproducible and stable organic soil based on the SOFIX database through testing a range of base soils and additive materials. This paper describes the process of control of the base soil and additive materials, the plant growth, and the bacterial analysis of the organic standard soil.

\section{Materials and Methods}

\subsection{The Study Area}

This study was carried out from November 2017 to September 2018 in the Faculty of Life Sciences, Ritsumeikan University, Kusatsu city, Shiga prefecture, Japan $\left(34^{\circ} 58^{\prime} 58.0^{\prime \prime} \mathrm{N} 135^{\circ} 57^{\prime} 49.2^{\prime \prime} \mathrm{E}\right)$.

\subsection{Materials}

Black soil (Kanuma Kosan, Tochigi, Japan), vermiculite (Kanuma Kosan), peat moss (Kanuma Kosan), mountain soil (Toyo company, Aichi, Japan), wood chip 1 (particle size $1 \mathrm{~cm}$; DaikenKogyo company, Osaka, Japan), and wood chip 2 (particle size $0.5 \mathrm{~cm}$; DaikenKogyo company, Osaka, Japan) were used for the 
base soil. Cow manure (Taniguchi Bokujo company, Shiga, Japan), horse manure from a horse ranch (Shiga, Japan), chicken manure from a chicken farm (Shiga, Japan), oil cake (JoY Agris company, Tokyo, Japan), soybean meal (Tamagoya company, Ibaraki, Japan), and bone meal (Tachikawa Heiwa Noen company, Tochigi, Japan) were used as the additive materials. The base soils and additive materials were air dried for 1 week, and then sieved through a $2-\mathrm{mm}$ sieve. The chemical soil (Hanachanbaiyodo company, Nagoya, Japan), which is amended with chemical fertilizer, was considered as a control treatment.

\subsection{Analytical Methods}

Total carbon (TC) was analyzed using a total organic carbon analyzer (SSM5000A, Shimadzu, Kyoto, Japan). Total nitrogen (TN), total phosphorus (TP), and total potassium (TK) contents were analyzed by extracting soil samples using the Kjeldahl digestion method followed by analysis using the indophenol blue method, molybdenum blue method, and atomic absorption spectrophotometry, respectively [15] [16]. The total bacterial biomass of the soil was analyzed by quantifying the environmental DNA (eDNA) extracted by the slow-stirring method [17]. Nitrogen $(\mathrm{N})$ circulation and phosphorus $(\mathrm{P})$ circulation activities were examined according to our previous studies [13] [18]. The maximum water holding capacity (WHC) and bulk density were measured by the standard methods [19]. Soil $\mathrm{pH}(1: 2.5$ soil-to-water suspension, w/v) was analyzed using a pH meter (LAQUA. F-71, Horiba, Kyoto, Japan).

\subsection{Preparation and Analysis of the Soil}

The base soils and additive materials were dried at $37^{\circ} \mathrm{C}$ for 1 week, and then these materials were sieved through a $2-\mathrm{mm}$ sieve. Seven organic soils were prepared by blending the base soils and additive materials. To activate the microbial activities, $200 \mathrm{~g}$ of each organic soil was preincubated in a $400 \mathrm{ml}$ pot and maintained $30 \%$ of water content for 1 week. The soil sample of each organic soil treatment was subsequently collected for SOFIX analysis [13]. The bacterial biomass was measured on days $0,3,5$, and 7 , while the other parameters were measured on days 0 and 7 . The bacterial diversity of the different lots of ideal standard organic soil and the different lots of chemical soils was analyzed on day 0 with polymerase chain reaction denaturing gradient gel electrophoresis (PCR-DGGE) analysis. The organic soils were incubated in the plant factory with $12 \mathrm{~h}$ of light: $12 \mathrm{~h}$ of dark at $23^{\circ} \mathrm{C}$ throughout the experimental period.

\subsection{Plant Cultivation}

Seven organic soils and the chemical soil (control) were used for plant cultivation experiment. A 2 L soil sample was put into a Wagner pot (1/5000a, Fujimoto Kagaku Kogyo company, Tokyo, Japan), and then preincubated at 30\% of water content. Brassica rapa var. peruviridis (Komatsuna) seeds were sown in a nursery tray for 1 week, and four seedlings were then transplanted to each Wagner 
pot. After 4 weeks of cultivation, B. rapa of each treatment were harvested and measured fresh weight, shoot length, root length, chlorophyll content, and the number of leaves. The parameters of $B$. rapa growth were determined using one-way analysis of variance (ANOVA).The leaf chlorophyll was analyzed by a chlorophyll meter (SPAD-502, Minolta, Tokyo, Japan) and described by SPAD reading values. The experiments were conducted in the plant factory $(12 \mathrm{~h}$ of light and $12 \mathrm{~h}$ of dark; $23^{\circ} \mathrm{C}$ ).

\subsection{PCR-DGGE Analysis}

A best organic standard soil (among seven organic soils) and the chemical soil (base soils + chemical fertilizer) were used for PCR-DGGE analysis. The 16S rRNA bacterial gene was amplified using primers DGGE-F (5'-CGCCC GCCGC GCCCC GCGCC CGTCC CGCCG CCCCC GCCCG CCTAC GGGAG GCAGC AG-3') and DGGE-R (5'-CCGTC AATTC CTTTG AGTTT-3') [20]. The amplification reaction was carried out in a $50 \mu \mathrm{L}$ PCR mixture containing $0.01 \mathrm{ng} / \mu \mathrm{L}$ of DNA template, $1.5 \mathrm{U}$ rTaq DNA polymerase, $5.0 \mu \mathrm{L}$ of $10 \times$ buffer, $5.0 \mu \mathrm{l}$ of 2 $\mathrm{mM}$ dNTPs, $3.0 \mu \mathrm{l}$ of $\mathrm{MgCl}_{2}$, and $2.0 \mu \mathrm{L}$ of $10 \mathrm{mmol} / \mathrm{L}$ of each primer. DNA polymerase, dNTPs, and PCR buffer were purchased from TOYOBO (Osaka, Japan), and all primers were synthesized by Sigma-Aldrich (Tokyo, Japan). The thermal PCR profile was as follows: initial denaturation at $95^{\circ} \mathrm{C}$ for $1 \mathrm{~min}$, followed by 35 cycles of denaturation at $95^{\circ} \mathrm{C}$ for $1 \mathrm{~min}$, primer annealing at $55^{\circ} \mathrm{C}$ for $30 \mathrm{~s}$, and extension at $72^{\circ} \mathrm{C}$ for $1 \mathrm{~min}$ and then a final extension at $72^{\circ} \mathrm{C}$ for 5 min. Finally, the amplified $16 \mathrm{~S}$ rRNA bacterial genes were used for denaturing gradient gel electrophoresis (DGGE) analysis.

DGGE was performed using the D Code System (BioRad Laboratories Inc., California, USA). A total of $20 \mu \mathrm{l}$ of PCR product was loaded into $8 \%(\mathrm{w} / \mathrm{v})$ poly acrylamide gel with a denaturant gradient of $27.5 \%-67.5 \%$. The gel was then run in $1 \times$ Tris-acetate EDTA buffer at a constant voltage of $70 \mathrm{~V}$ at $60^{\circ} \mathrm{C}$ for 15 $\mathrm{h}$. The gel was stained using ethidium bromide for $30 \mathrm{~min}$, then rinsed with distilled water. Cluster analysis of the DGGE band pattern was subsequently conducted using the FPQuest Bioinformatics Software (BioRad Laboratories Inc., California, USA).

\section{Results}

\subsection{Selection of the Base Soils and Additive Materials}

Base soils and additive materials were selected to construct suitable chemical, physical, and biological characteristics in the organic standard soil. The properties of candidates for the base soil (mountain soil, black soil, peat moss, vermiculite, and wood chips) were measured (Table 1 and Table 2). The TC contents of peat moss and wood chips were higher than those of the other candidate base soils, while the TN and the TP contents of all candidates were low. The maximum WHC of black soil, vermiculite, and wood chips were relatively high but the bulk density of vermiculite, peat moss, and wood chips were low. The components 
Table 1. The chemical properties of the base soils and additive materials.

\begin{tabular}{cccccccc}
\hline \multirow{2}{*}{ Material } & $\begin{array}{c}\mathrm{TC} \\
(\mathrm{mg} / \mathrm{kg})\end{array}$ & $\begin{array}{c}\mathrm{TN} \\
(\mathrm{mg} / \mathrm{kg})\end{array}$ & $\begin{array}{c}\mathrm{TP} \\
(\mathrm{mg} / \mathrm{kg})\end{array}$ & $\begin{array}{c}\mathrm{TK} \\
(\mathrm{mg} / \mathrm{kg})\end{array}$ & $\begin{array}{c}\mathrm{C} / \mathrm{N} \\
\text { ratio }\end{array}$ & $\begin{array}{c}\mathrm{C} / \mathrm{P} \\
\text { ratio }\end{array}$ \\
\hline \multirow{3}{*}{ Base soil } & Black soil & 69,500 & 1770 & 2070 & 4000 & 39 & 34 \\
& Mountain soil & 300 & 90 & 410 & 8000 & 3 & 1 \\
& Vermiculite & 400 & 180 & 300 & 33,000 & 2 & 1 \\
& Peat moss & 412,200 & 2070 & 310 & 1300 & 199 & 1330 \\
& Wood chip 1 & 445,100 & 700 & 270 & 2500 & 636 & 1649 \\
& Wood chip 2 & 356,000 & 470 & 270 & 2600 & 757 & 1319 \\
\multirow{2}{*}{ Additive } \\
material & Oil cake & 416,900 & 51,200 & 18,200 & 14,000 & 8 & 23 \\
& Soybean meal & 405,900 & 66,800 & 7,350 & 24,200 & 7 & 55 \\
& Bone meal & 211,400 & 40,600 & 75,880 & 3600 & 5 & 3 \\
& Chicken manure & 194,000 & 34,600 & 17,500 & 24,400 & 6 & 11 \\
& Horse manure & 113,600 & 4729 & 3350 & 4330 & 24 & 34 \\
& Cow manure & 330,000 & 21,000 & 10,000 & 26,000 & 16 & 33 \\
\hline
\end{tabular}

Table 2. The bacterial biomass and physical properties of the base soils and additive materials.

\begin{tabular}{|c|c|c|c|c|c|}
\hline & Material & $\begin{array}{l}\text { Bacterial biomass } \\
\left(\times 10^{8} \text { cells/g-soil }\right)\end{array}$ & $\begin{array}{c}\text { Water holding } \\
\text { capacity }(\mathrm{ml} / \mathrm{kg})\end{array}$ & $\begin{array}{l}\text { Bulk density } \\
\quad\left(\mathrm{g} / \mathrm{cm}^{3}\right)\end{array}$ & $\begin{array}{c}\text { Water content } \\
(\%)\end{array}$ \\
\hline \multirow{6}{*}{ Base soil } & Black soil & N.D. & 980 & 0.84 & 1.2 \\
\hline & Mountain soil & N.D. & 550 & 1.39 & 29.6 \\
\hline & Vermiculite & N.D. & 3000 & 0.22 & 0.2 \\
\hline & Peat moss & N.D. & 300 & 0.14 & 3.6 \\
\hline & Wood chip 1 & 2.7 & 1150 & 0.15 & 12.3 \\
\hline & Wood chip 2 & 8.8 & 1120 & 0.10 & 9.2 \\
\hline \multirow{6}{*}{$\begin{array}{l}\text { Additive } \\
\text { material }\end{array}$} & Oil cake & N.D. & - & - & - \\
\hline & Soybean meal & N.D. & - & - & - \\
\hline & Bone meal & N.D. & - & - & - \\
\hline & Chicken manure & 7.8 & - & - & - \\
\hline & Horse manure & 71.0 & - & - & - \\
\hline & Cow manure & 132.4 & - & - & - \\
\hline
\end{tabular}

N.D. $=$ not detected

difference sizes of wood chips (wood chips 1 and wood chips 2) were almost the same but the bacterial biomass of a wood chip 2 was higher than that of a wood chip 1 .

The total nitrogen contents of oil cake, soybean meal, bone meal, chicken manure, and cow manure were above $20,000 \mathrm{mg} / \mathrm{kg}$. The TP contents of oil cake, bone meal, chicken manure, and cow manure were high. The bacterial biomass of all manures was above $6 \times 10^{8}$ cells $/ g$. Among the three types of manure, cow 
manure was selected because of a well-balanced nutrient content and high bacterial biomass.

\subsection{Construction and Characterization of the Organic Standard Soils}

The candidates of a standard soil based on SOFIX recommended values (Table 3) were prepared to construct a stable and reproducible organic standard soil. Seven candidates of the organic standard soil were prepared using the base soils and additive materials at different ratios (Table 4 and Table 5). Cow manure, oil cake, soybean meal, and bone meal were added in base soil at $5 \%, 0.25 \%, 0.25 \%$, and $0.05 \% \mathrm{w} / \mathrm{w}$, respectively.

Chemical and physical properties of the seven prepared organic standard soils are shown in Table 6. The TC, TN, TP, and TK contents, and the $\mathrm{C} / \mathrm{N}$ and $\mathrm{C} / \mathrm{P}$ ratios of the seven candidate standard soils were $24,000-34,740 \mathrm{mg} / \mathrm{kg}, 1580$ $1840 \mathrm{mg} / \mathrm{kg}, 1040-1160 \mathrm{mg} / \mathrm{kg}$, and $6450-9660 \mathrm{mg} / \mathrm{kg}$, and $14-20$ and $22-31$, respectively. The bulk density and the WHC of the seven organic standard soils were above $0.5 \mathrm{~g} / \mathrm{cm}^{3}$ and $1200 \mathrm{ml} / \mathrm{kg}$, respectively. The chemical and physical properties of the seven organic soils were around SOFIX recommended values. Among seven organic soils, T7 was showed the lowest bulk density but the highest WHC.

The biological properties of the seven candidate organic soils after controlling the water (30\% of water content) for 1 week are shown in Figure 1 and Table 7. The bacterial biomass of all candidate organic soils exceeded $6 \times 10^{8}$ cells/g-soil on day 3, and the bacterial biomass of T2, T3, T4, T5, T6, and T7 was greater than $11 \times 10^{8}$ cells/g-soil on day 7 . This result indicates that the wood chips increase the bacterial biomass. Among the seven organic soils, T7 showed the highest value of the bacterial biomass. The nitrogen and phosphorus circulation activities of the seven candidates of the organic soil were close to the SOFIX recommended values.

\subsection{Plant Growth in the Organic Standard Soils}

To compare the plant growth, $B$. rapa cultivation experiment was conducted (Table 8). The performance of Brassica rapa in the seven organic soils was similar

Table 3. The SOFIX recommended value.

\begin{tabular}{cc}
\hline Parameter & Recommended value \\
\hline Total carbon $(\mathrm{TC})(\mathrm{mg} / \mathrm{kg})$ & $\geq 25,000$ \\
Total nitrogen $(\mathrm{TN})(\mathrm{mg} / \mathrm{kg})$ & $\geq 1500$ \\
Total phosphorus $(\mathrm{TP})(\mathrm{mg} / \mathrm{kg})$ & $2500-10,000$ \\
Total potassium $(\mathrm{TK})(\mathrm{mg} / \mathrm{kg})$ & $8-25$ \\
C/N ratio & $23-46$ \\
C/P ratio & $\geq 38$ \\
N circulation activity (point) & $30-70$ \\
P circulation activity (point) & \\
\hline
\end{tabular}


Table 4. The blend of the organic soils.

\begin{tabular}{ccccccc}
\hline \multirow{2}{*}{ Organic soil } & \multicolumn{5}{c}{ Base soil (\% v/v) } \\
\cline { 2 - 7 } & $\begin{array}{c}\text { Mountain } \\
\text { soil }\end{array}$ & Black soil & Vermiculite & Peat moss & $\begin{array}{c}\text { Wood } \\
\text { chip 1 }\end{array}$ & $\begin{array}{c}\text { Wood } \\
\text { chip 2 }\end{array}$ \\
\hline T1 & 30 & 10 & 50 & 10 & - & - \\
T2 & 30 & 10 & - & 10 & 50 & - \\
T3 & 30 & 10 & - & - & 60 & - \\
T4 & 20 & 10 & - & - & 70 & - \\
T5 & 30 & 10 & - & 10 & - & 50 \\
T6 & 30 & 10 & - & - & - & 60 \\
T7 & 20 & 10 & - & - & - & 70 \\
\hline
\end{tabular}

Table 5. The blend of the organic soils.

\begin{tabular}{ccccc}
\hline \multirow{2}{*}{ Organic soil } & \multicolumn{4}{c}{ Additive material $(\% \mathrm{w} / \mathrm{w})$} \\
\cline { 2 - 4 } & Cow manure & Oil cake & Soybean meal & Bone meal \\
\hline T1 - T7 & 5 & 0.25 & 0.25 & 0.05 \\
\hline
\end{tabular}

Table 6. The chemical and physical properties of the organic soils (Unit: $\mathrm{mg} / \mathrm{kg}$ air dried soil).

\begin{tabular}{ccccccccc}
\hline $\begin{array}{c}\text { Organic } \\
\text { soil }\end{array}$ & $\begin{array}{c}\mathrm{TC} \\
(\mathrm{mg} / \mathrm{kg})^{*}\end{array}$ & $\begin{array}{c}\mathrm{TN} \\
(\mathrm{mg} / \mathrm{kg})\end{array}$ & $\begin{array}{c}\mathrm{TP} \\
(\mathrm{mg} / \mathrm{kg})\end{array}$ & $\begin{array}{c}\mathrm{TK} \\
(\mathrm{mg} / \mathrm{kg})\end{array}$ & $\begin{array}{c}\mathrm{C} / \mathrm{N} \\
\text { ratio }\end{array}$ & $\begin{array}{c}\mathrm{C} / \mathrm{P} \\
\text { ratio }\end{array}$ & $\begin{array}{c}\text { Bulk } \\
\text { density } \\
\left(\mathrm{g} / \mathrm{cm}^{3}\right)\end{array}$ & $\begin{array}{c}\text { Water holding } \\
\text { capacity } \\
(\mathrm{ml} / \mathrm{kg})\end{array}$ \\
\hline $\mathrm{T} 1$ & 31,550 & 1650 & 1040 & 9660 & 19 & 30 & 0.69 & 1328 \\
$\mathrm{~T} 2$ & 34,400 & 1740 & 1130 & 7510 & 19 & 31 & 0.59 & 1340 \\
$\mathrm{~T} 3$ & 24,000 & 1580 & 1090 & 7120 & 15 & 23 & 0.63 & 1297 \\
$\mathrm{~T} 4$ & 26,120 & 1840 & 1120 & 6460 & 14 & 24 & 0.51 & 1332 \\
$\mathrm{~T} 5$ & 34,740 & 1690 & 1130 & 7550 & 20 & 31 & 0.58 & 1362 \\
$\mathrm{~T} 6$ & 25,350 & 1650 & 1160 & 7920 & 15 & 22 & 0.55 & 1338 \\
$\mathrm{~T} 7$ & 26,350 & 1690 & 1120 & 6450 & 15 & 24 & 0.50 & 1407 \\
\hline
\end{tabular}

${ }^{*} \mathrm{TC}$ was determined without wood.

Table 7. $\mathrm{N}$ and $\mathrm{P}$ circulation activites of the organic soils.

\begin{tabular}{|c|c|c|c|c|}
\hline \multirow{3}{*}{ Organic soil } & \multicolumn{2}{|c|}{$\mathrm{N}$ circulation (point) } & \multicolumn{2}{|c|}{$\mathrm{P}$ circulation (point) } \\
\hline & \multicolumn{2}{|c|}{ Day } & \multicolumn{2}{|c|}{ Day } \\
\hline & 0 & 7 & 0 & 7 \\
\hline $\mathrm{T} 1$ & 31 & 36 & 54 & 47 \\
\hline $\mathrm{T} 2$ & 22 & 32 & 57 & 31 \\
\hline T3 & 47 & 37 & 54 & 58 \\
\hline $\mathrm{T} 4$ & 34 & 42 & 54 & 49 \\
\hline T5 & 34 & 45 & 39 & 72 \\
\hline T6 & 35 & 54 & 63 & 37 \\
\hline T7 & 14 & 50 & 60 & 53 \\
\hline
\end{tabular}


Table 8. Parameters of Brassica rapa growth in the organic soils and the chemical soil.

\begin{tabular}{cccccc}
\hline Treatment & $\begin{array}{c}\text { Fresh weight } \\
(\mathrm{g} / \mathrm{plant})\end{array}$ & $\begin{array}{c}\text { Shoot length } \\
(\mathrm{cm})\end{array}$ & $\begin{array}{c}\text { Root length } \\
(\mathrm{cm})\end{array}$ & $\begin{array}{c}\text { Chlorophyll } \\
(\text { SPAD reading })\end{array}$ & $\begin{array}{c}\text { Number of } \\
\text { leaves }\end{array}$ \\
\hline \multirow{2}{*}{ T1 } & $3.4^{\mathrm{a}} \pm 0.8$ & $19.0^{\mathrm{a}} \pm 2.2$ & $11.5^{\mathrm{a}} \pm 3.1$ & $25.3^{\mathrm{b}} \pm 3.1$ & $6^{\mathrm{a}} \pm 1.1$ \\
& $(98 \%)$ & $(117 \%)$ & $(85 \%)$ & $(76 \%)$ & $(85 \%)$ \\
T2 & $3.5^{\mathrm{a}} \pm 1.1$ & $18.4^{\mathrm{a}} \pm 1.9$ & $10.3^{\mathrm{a}} \pm 2.1$ & $24.4^{\mathrm{b}} \pm 3.2$ & $7^{\mathrm{a}} \pm 1.0$ \\
& $(96 \%)$ & $(113 \%)$ & $(76 \%)$ & $(73 \%)$ & $(100 \%)$ \\
T3 & $3.4^{\mathrm{a}} \pm 1.6$ & $17.1^{\mathrm{a}} \pm 7.1$ & $11.0^{\mathrm{a}} \pm 4.3$ & $23.8^{\mathrm{b}} \pm 4.0$ & $6^{\mathrm{a}} \pm 0.7$ \\
& $(98 \%)$ & $(105 \%)$ & $(81 \%)$ & $(71 \%)$ & $(85 \%)$ \\
T4 & $4.4^{\mathrm{a}} \pm 1.0$ & $18.9^{\mathrm{a}} \pm 4.1$ & $14.3^{\mathrm{a}} \pm 5.4$ & $25.7^{\mathrm{b}} \pm 4.1$ & $7^{\mathrm{a}} \pm 1.4$ \\
& $(118 \%)$ & $(116 \%)$ & $(105 \%)$ & $(77 \%)$ & $(100 \%)$ \\
T5 & $3.9^{\mathrm{a}} \pm 1.1$ & $18.7^{\mathrm{a}} \pm 2.7$ & $13.4^{\mathrm{a}} \pm 4.7$ & $23.8^{\mathrm{b}} \pm 1.8$ & $6^{\mathrm{a}} \pm 0.9$ \\
& $(105 \%)$ & $(115 \%)$ & $(99 \%)$ & $(71 \%)$ & $(85 \%)$ \\
T6 & $4.3^{\mathrm{a}} \pm 1.0$ & $20.9^{\mathrm{a}} \pm 2.2$ & $13.1^{\mathrm{a}} \pm 2.3$ & $24.5^{\mathrm{b}} \pm 3.9$ & $7^{\mathrm{a}} \pm 0.9$ \\
& $(116 \%)$ & $(129 \%)$ & $(97 \%)$ & $(73 \%)$ & $(100 \%)$ \\
T7 & $4.7^{\mathrm{a}} \pm 2.1$ & $19.7^{\mathrm{a}} \pm 2.5$ & $13.3^{\mathrm{a}} \pm 2.4$ & $27.0^{\mathrm{b}} \pm 3.5$ & $6^{\mathrm{a}} \pm 0.7$ \\
& $(127 \%)$ & $(121 \%)$ & $(98 \%)$ & $(81 \%)$ & $(85 \%)$ \\
Chemical & $3.7^{\mathrm{a}} \pm 1.7$ & $16.2^{\mathrm{a}} \pm 2.7$ & $13.5^{\mathrm{a}} \pm 2.1$ & $33.2^{\mathrm{a}} \pm 2.5$ & $7^{\mathrm{a}} \pm 0.5$ \\
(control) & $(100 \%)$ & $(100 \%)$ & $(100 \%)$ & $(100 \%)$ & $(100 \%)$ \\
\hline
\end{tabular}

Means followed by the same letter do not significantly differ $(p<0.05)$. Value followed by \pm is standard deviation.

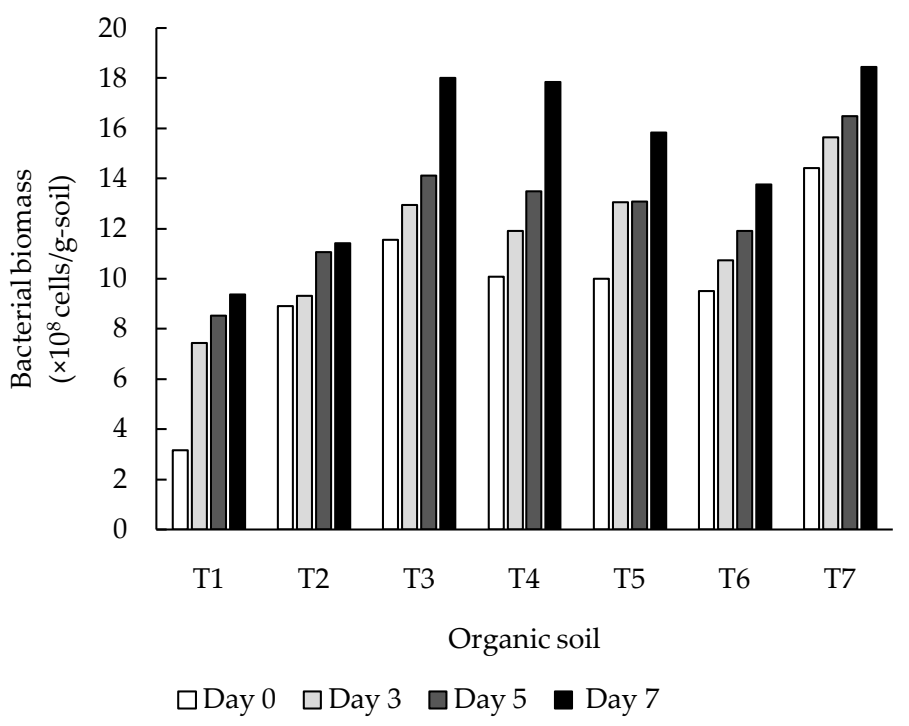

Figure 1. The bacterial biomass in the seven organic soils (T1-T7) during 7 days.

or better than that in the chemical soil. An increase of wood chip 2 led to a higher fresh weight and shoot length of $B$. rapa than that in the chemical soil and in the organic soils with wood chip 1. Especially, B. rapa growth in the organic soil T7 containing $70 \%(\mathrm{v} / \mathrm{v})$ of wood chip 2 was the highest. These findings suggest that wood chip 2 is the most suitable for $B$. rapa cultivation. Chlorophyll of plants in the chemical soil used was $19 \%-29 \%$ higher than those in the organic soils, suggesting that the inorganic nitrogen in the chemical soil was richer than that in the organic soil. 
As a result, the organic soil T7 was identified as the best organic standard soil. In the next experiment, comparison of the bacterial diversity between the organic standard soil (T7) and the chemical soil was conducted.

\subsection{Analysis of the Bacterial Diversity in the Organic Standard Soil}

The comparison of the bacterial diversity between the organic standard soil (T7) and the chemical soil were conducted in this study. The bacterial diversities of different lots of the organic standard soil and different lots of the chemical soil were compared (Figure 2). The bacterial diversities of the organic standard soil and the chemical soil were different, even though the same base soil was used in the organic standard soil and the chemical soil. The bacterial diversities of the organic standard soil were similar, but those of different lots of the chemical soil were unstable. The number of bacterial species in the organic standard soil was higher than that in the chemical soil. The organic standard soil was controlled not only by the bacterial biomass but also by the bacterial diversity, suggesting that the bacteria biomass and bacterial diversity seem to be a positive relationship.

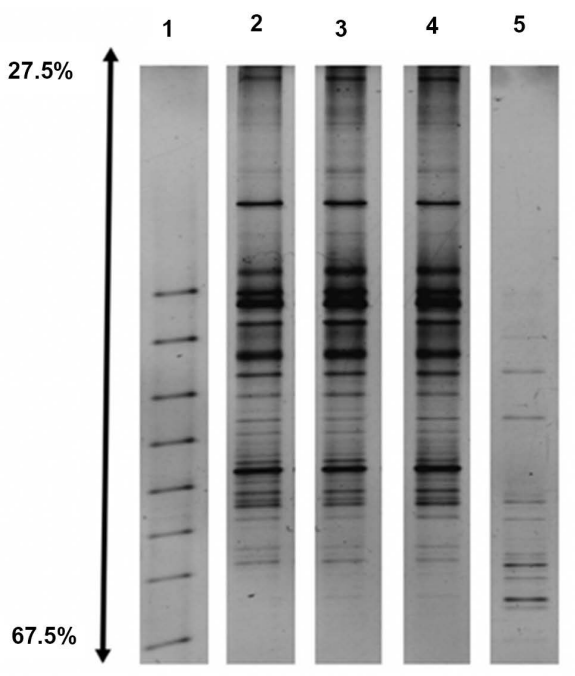

(a)
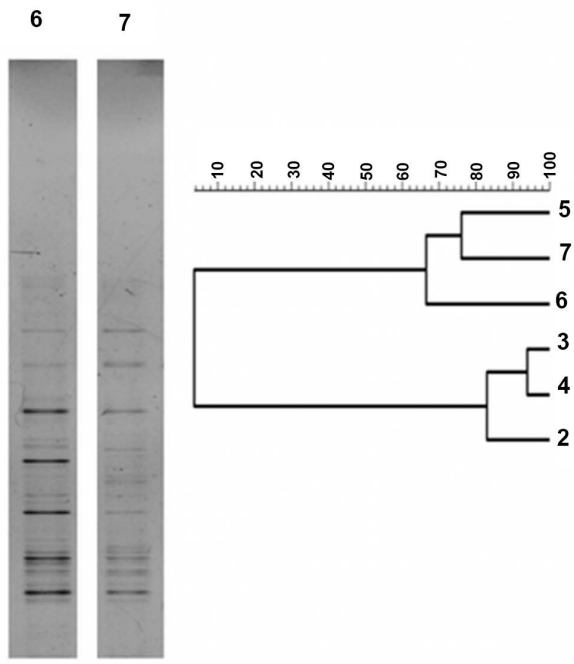

(b)

Figure 2. PCR DGGE analysis of $16 \mathrm{~S}$ rRNA bacterial genes: image of electrophoresis (1: Marker, 2 - 4: Different lots of the organic standard soil, and 5 - 7: Different lots of the chemical soil) (a) and cluster analysis (b).

\section{Discussion}

Based on SOFIX database [13], the values of TC $(\geq 25,000 \mathrm{mg} / \mathrm{kg}), \mathrm{TN}(\geq 1500$ $\mathrm{mg} / \mathrm{kg}$ ), TP ( $\geq 1100 \mathrm{mg} / \mathrm{kg}$ ), TK (2500 to $10,000 \mathrm{mg} / \mathrm{kg}$ ), and C/N ratio (8 to 25 ) were controlled by mountain soil, black soil, wood chips, peat moss, vermiculite, and additive materials. The bacterial biomass of the organic soils with wood chips was higher than $6 \times 10^{8}$ cells/g-soil after controlling the water content to $30 \%$. Wood chips, especially the small particle size (wood chips 2 ), were found to 
be most suitable for the bacteria growth and diversity. The surface area and pore size of wood chips may be suitable for soil microorganisms [21] [22]. In fact, the bacterial biomass in the organic soils with wood chips 2 were obviously higher $\left(\geq 14 \times 10^{8}\right.$ cells/g) than that in vermiculite after 7 days. Moreover, the bacterial biomass in the organic soils was also higher than those in organic farming soils [23].

The growth of B. rapa in the organic standard soil was higher than that in the chemical soil. Soil microorganisms play an important role in soil nutrientcycling [24] [25]. The supply of nitrogen, phosphorus, potassium, and other minerals in organic materials for plants via the material circulations in soil seems to be as sufficient for growth of the plant as that of chemical fertilizers [23] [24] [25] [26]. The organic standard soil could be used in limited areas of agricultural fields such as greenhouse.

The bacterial biomass was low under the dry conditions in the organic standard soil. However, the bacterial biomass was drastically increased after controlling the water content in the short term [27] [28] [29]. Subsequently, nitrogen and phosphorus circulation activities based on the additive materials occurred after increasing the bacterial biomass. Our results indicate that the organic standard soil led to increased richness and diversity of soil microbes relative to the chemical soil. Many studies have confirmed that the soil microbes are often more diverse and abundant under organic than conventional systems [30] [31] [32] [33]. In addition, the bacterial diversities in the organic standard soil became almost the same within the PCR-DGGE experiment [34], indicating that the preparation of the organic standard soil was reproducible. The bacterial diversity was also controlled reproducibly by the addition of the water.

In this study, the main elements (nitrogen, phosphorus, and potassium) in the organic standard soil were successfully controlled by biomass resources based on the SOFIX database. Other factors, such as micronutrients, will be considered in the next stage of the organic soil construction, which is currently in progress.

\section{Conclusion}

The reproducible and stable organic standard soil was constructed in this study. All organic soils showed the suitable values of chemical and biological properties according to SOFIX recommended values. Out of those, T7 (with 70\% of smallsized wood chip) had the highest bacterial biomass and stable bacterial diversity. In addition, $\mathrm{T} 7$ led to the increase of the fresh weight of $B$. rapa.

\section{Conflicts of Interest}

The authors declare no conflicts of interest regarding the publication of this paper.

\section{References}

[1] Matson, P.A., Parton, W.J., Power, A.G. and Swift, M.J. (1997) Agricultural Intensifi- 
cation and Ecosystem Properties. Science, 277, 504-509.

https://doi.org/10.1126/science.277.5325.504

[2] Singh, B.K., Kuhad, R.C., Singh, A., Lal, R. and Tripathi, K.K. (1999) Biochemical and Molecular Basis of Pesticide Degradation by Microorganisms. Critical Reviews in Biotechnology, 19, 197-225. https://doi.org/10.1080/0738-859991229242

[3] Bollen, W.B. (1961) Interactions between Pesticides and Soil Microorganisms. Annual Review of Microbiology, 15, 69-92. https://doi.org/10.1146/annurev.mi.15.100161.000441

[4] Toyota, K., Ritz, K. and Young, I.M. (1996) Survival of Bacterial and Fungal Populations Following Chloroform-Fumigation: Effects of Soil Matric Potential and Bulk Density. Soil Biology and Biochemistry, 28, 1545-1547. https://doi.org/10.1016/S0038-0717(96)00162-9

[5] Singh, J., Singh, S., Vig, A.P., Bhat, S.A., Hundal, S.S., Yin, R. and Schädler, M. (2018) Conventional Farming Reduces the Activity of Earthworms: Assessment of Genotoxicity Test of Soil and Vermicast. Agriculture and Natural Resources, 52, 366-370. https://doi.org/10.1016/j.anres.2018.10.012

[6] Mäder, P., Fliessbach, A., Dubois, D., Gunst, L., Fried, P. and Niggli, U. (2002) Soil Fertility and Biodiversity in Organic Farming. Science, 296, 1694-1697.

https://doi.org/10.1126/science.1071148

[7] Tsiafouli, M.A., Thébault, E., Sgardelis, S.P., De Ruiter, P.C., Van Der Putten, W.H., Birkhofer, K., Hemerik, L., De Vries, F.T., Bardgett, R.D., Brady, M.V., Bjornlund, L., Jørgensen, H.B., Christensen, S., Hertefeldt, T.D., Hotes, S., Hol, W.H.G., Frouz, J., Liiri, M., Mortimer, S.R., Setälä, H., Tzanopoulos, J., Uteseny, K., Pižl, V., Stary, J., Wolters, V. and Hedlund, K. (2014) Intensive Agriculture Reduces Soil Biodiversity across Europe. Global Change Biology, 21, 973-985.

https://doi.org/10.1111/gcb.12752

[8] Kennedy, A.C. (1999) Bacterial Diversity in Agroecosystems. Agriculture, Ecosystems and Environment, 74, 65-76.

https://doi.org/10.1016/S0167-8809(99)00030-4

[9] Buckley, D.H. and Schmidt, T.M. (2001) The Structure of Microbial Communities in Soil and the Lasting Impact of Cultivation. Microbial Ecology, 42, 11-21.

[10] Bünemann, E.K. and Condron, L.M. (2007) Phosphorus and Sulphur Cycling in Terrestrial Ecosystems. In: Nutrient Cycling in Terrestrial Ecosystems, Springer, Berlin Heidelberg, Vol. 10, 65-92. https://doi.org/10.1007/978-3-540-68027-7_3

[11] Khan, A.A., Jilani, G., Akhtar, M.S., Naqvi, S.M.S. and Rasheed, M. (2009) Phosphorus Solubilizing Bacteria: Occurrence, Mechanisms and Their Role in Crop Production. Journal of Agricultural and Biological Sciences, 1, 48-58.

[12] Scherer, H.W. (2009) Sulfur in Soils. Journal of Plant Nutrition and Soil Science, 172, 326-335. https://doi.org/10.1002/jpln.200900037

[13] Adhikari, D., Kai, T., Mukai, M., Araki, K.S. and Kubo, M. (2014) Proposal for a New Soil Fertility Index (SOFIX) for Organic Agriculture and Construction of a SOFIX Database for Agricultural Fields. Current Topics in Biotechnology, 8, 81-91.

[14] Daiken Kogyo Company, Osaka, Japan (2019) Wood Biomass as Soil Amendment and Manufacture Method (Japanese). https://ipforce.jp/patent-jp-B9-6469143

[15] Donald Nicholas, D.J. and Nason, A. (1975) Determination of Nitrate and Nitrite. Methods in Enzymology, 3, 981-984.

https://doi.org/10.1016/S0076-6879(57)03489-8

[16] Murphy, J. and Riley, J.P. (1962) A Modified Single Solution Method for the Deter- 
mination of Phosphate in Natural Waters. Analytical Chimica Acta, 27, 31-36. https://doi.org/10.1016/S0003-2670(00)88444-5

[17] Aoshima, H., Kimura, A., Shibutani, A., Okada, C., Matsumiya, Y. and Kubo, M. (2006) Evaluation of Soil Bacterial Biomass Using Environmental DNA Extracted by Slow-Stirring Method. Applied Microbiology and Biotechnology, 71, 875-880. https://doi.org/10.1007/s00253-005-0245-x

[18] Horii, S., Matsuno, T., Tagomori, J., Mukai, M., Adhikari, D. and Kubo, M. (2013) Isolation and Identification of Phytate-Degrading Bacteria and Their Contribution to Phytate Mineralization in Soil. The Journal of General and Applied Microbiology, 59, 353-360. https://doi.org/10.2323/jgam.59.353

[19] Lestariningsih, I.D. and Hairiah, W.K. (2013) Assessing Soil Compaction with Two Different Methods of Soil Bulk Density Measurement in Oil Palm Plantation Soil. Procedia Environmental Sciences, 17, 172-178. https://doi.org/10.1016/j.proenv.2013.02.026

[20] Adhikari, D., Mukai, M., Kubota, K., Kai, T., Kaneko, N.K., Araki, K.S. and Kubo, M. (2016) Degradation of Bioplastic in Soil and Their Degradation Effects on Environmental Microorganisms. Journal of Agricultural Chemistry and Environment, 5, 23-24. https://doi.org/10.4236/jacen.2016.51003

[21] Stanzl-Tschegg, S.E. (2001) Wood as a Bioinspiring Material. Materials Science and Engineering, 31, 1174-1183. https://doi.org/10.1016/j.msec.2010.12.001

[22] Hellenbrand, K.E. and Reade, A.E. (1992) Microorganisms Associated with Fuel Wood Chips and Their Impact on Indoor Air Quality: A Review. International Biodeterioration and Biodegradation, 29, 19-43. https://doi.org/10.1016/0964-8305(92)90004-8

[23] Adhikari, D., Kobashi, K., Kai, T., Kawagoe, T., Kubota, K., Araki, K.S. and Kubo, M. (2018) Suitable Soil Conditions for Tomato Cultivation under an Organic Farming System. Journal of Agricultural Chemistry and Environment, 7, 117-132. https://doi.org/10.4236/jacen.2018.73011

[24] Deacon, L.J., Pryce-Miller, E.J., Frankland, J.C., Bainbridge, B.W., Moore, P.D. and Robinson, C.H. (2006) Diversity and Function of Decomposer Fungi from a Grassland Soil. Soil Biology and Biochemistry, 38, 7-20. https://doi.org/10.1016/j.soilbio.2005.04.013

[25] Seiter, S., Ingham, E.R. and William, R.D. (1999) Dynamics of Soil Fungal and Bacterial Biomass in a Temperate Climate Alley Cropping System. Applied Soil Ecology, 12, 139-147. https://doi.org/10.1016/S0929-1393(98)00163-2

[26] Xiao, C.W., Janssens, I.A., Liu, P., Zhou, Z.Y. and Sun, O.J. (2007) Irrigation and Enhanced Soil Carbon Input Effects on Below-Ground Carbon Cycling in Semiarid Temperate Grasslands. New Phytologist, 174, 835-846. https://doi.org/10.1111/j.1469-8137.2007.02054.x

[27] Lund, V. and Gorksoyr, J. (1980) Effects of Water Fluctuations on Microbial Mass and Activity in Soil. Microbial Ecology, 6, 115-123. https://doi.org/10.1007/BF02010550

[28] Sparling, G.P., Murphy, D.V., Thompson, R.B. and Fillery, I.R.P. (1995) Short-Term Net N Mineralization from Plant Residues and Gross and Net N Mineralization from Soil Organic Matter after Rewetting of a Seasonally Dry Soil. Australian Journal of Soil Research, 33, 961-973. https://doi.org/10.1071/SR9950961

[29] Collins, S.L., Sinsabaugh, R.L., Crenshaw, C., Green, L., Porras-Alfaro, A., Stursova, M. and Zeglin, L.H. (2008) Pulse Dynamics and Microbial Processes in Aridland Ecosystems. Journal of Ecology, 96, 413-420. 
https://doi.org/10.1111/j.1365-2745.2008.01362.x

[30] Crowder, D.W., Northfield, T.D., Strand, M.R. and Snyder, W.E. (2010) Organic Agriculture Promotes Evenness and Natural Pest Control. Nature, 466, 109-112. https://doi.org/10.1038/nature09183

[31] Klaus, V.H., Kleinebecker, T., Prati, D., Gossner, M.M., Alt, F., Boch, S., Gockel, S., Hemp, A., Lange, M., Muiller, J., Oelmann, Y., Pasalic, E., Renner, S.C., Socher, S.A.,Türke, M., Weisser, W.W., Fischer, M. and Holzel, N. (2013) Does Organic Grassland Farming Benefit Plant and Arthropod Diversity at the Expense of Yield and Soil Fertility? Agriculture, Ecosystems and Environment, 177, 1-9. https://doi.org/10.1016/j.agee.2013.05.019

[32] Hole, D.G., Perkins, A.J., Wilson, J.D., Alexander, I.H., Grice, P.V. and Evans, A.D. (2005) Does Organic Farming Benefit Biodiversity? Biological Conservation, 122, 113-130. https://doi.org/10.1016/j.biocon.2004.07.018

[33] Whittingham, M.J. (2011) The Future of Agri-Environment Schemes: Biodiversity Gains and Ecosystem Service Delivery? Journal of Applied Ecology, 48, 509-513. https://doi.org/10.1111/j.1365-2664.2011.01987.x

[34] Wang, W., Wang, H., Feng, Y., Wang, L., Xiao, X., Xi, Y., Luo, X., Sun, R., Ye, X., Huang, Y., Zhang, Z. and Cui, Z. (2016) Consistent Responses of the Microbial Community Structure to Organic Farming along the Middle and Lower Reaches of the Yangtze River. Scientific Reports, 6, 1-11. https://doi.org/10.1038/srep35046 